
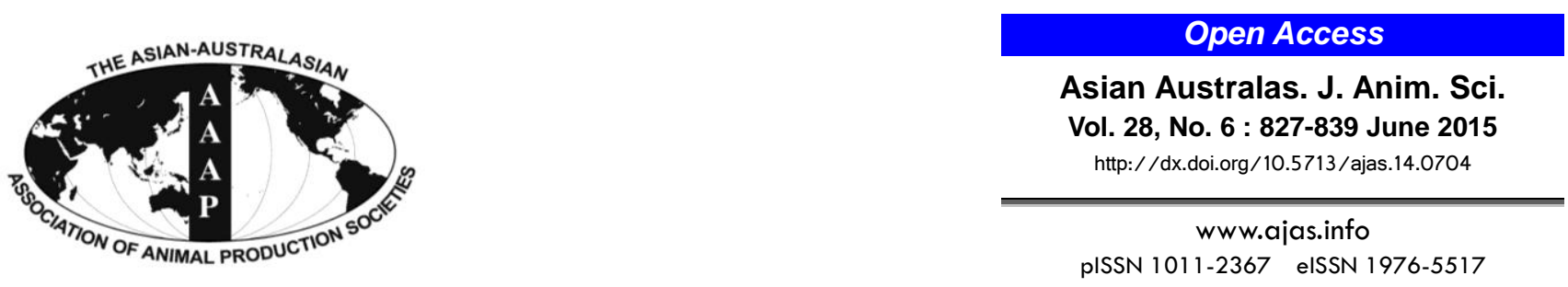

\title{
Effects of Benzoic Acid and Thymol on Growth Performance and Gut Characteristics of Weaned Piglets
}

\author{
Hui Diao ${ }^{\text {a }}$, Ping Zheng ${ }^{\text {a }}$, Bing Yu, Jun He, Xiangbing Mao, Jie Yu, and Daiwen Chen* \\ Institute of Animal Nutrition, Sichuan Agricultural University, Sichuan 625014, China
}

\begin{abstract}
A total of 144 weaned crossed pigs were used in a 42-d trial to explore the effects of different concentrations/ combinations of benzoic acid and thymol on growth performance and gut characteristics in weaned pigs. Pigs were randomly allotted to 4 dietary treatments: i) control (C), basal diet, ii) C+1,000 mg/kg benzoic acid+100 mg/kg thymol (BT1), iii) C+1,000 mg/kg benzoic acid+200 mg/kg thymol (BT2) and, iv) C+2,000 mg/kg benzoic acid+100 mg/kg thymol (BT3). Relative to the control, pigs fed diet BT3 had lower diarrhoea score during the overall period $(\mathrm{p}<0.10)$ and improved feed to gain ratio between days 1 to 14 ( $\mathrm{p}<0.05)$, which was accompanied by improved apparent total tract digestibility of ether extract, Ca and crude ash ( $\mathrm{p}<0.05)$, and larger lipase, lactase and sucrose activities in the jejunum $(\mathrm{p}<0.05)$ at $\mathrm{d} 14$ and $\mathrm{d} 42$. Similarly, relative to the control, pigs fed diet BT3 had higher counts for Lactobacillus spp in digesta of ileum at d 14 ( $<<0.05)$, and pigs fed diets BT1, BT2, or BT3 also had higher counts of Bacillus spp in digesta of caecum at d $14(\mathrm{p}<0.05)$, and lower concentration of ammonia nitrogen in digesta of caecum at $d 14$ and $d 42(p<0.05)$. Finally, pigs fed diet BT3 had higher concentration of butyric acid in digesta of caecum at d $42(\mathrm{p}<0.05)$, and a larger villus height:crypt depth ratio in jejunum and ileum at $\mathrm{d} 14(\mathrm{p}<0.05)$ than pigs fed the control diet. In conclusion, piglets fed diet supplementation with different concentrations/combinations of benzoic acid and thymol could improve feed efficiency and diarrhoea, and improve gut microfloral composition. The combination of $2,000 \mathrm{mg} / \mathrm{kg}$ benzoic acid $+100 \mathrm{mg} / \mathrm{kg}$ thymol produced better effects than other treatments in most measurements. (Key Words: Benzoic Acid, Thymol, Growth Performance, Microflora, Gut Histo-morphology, Piglets)
\end{abstract}

\section{INTRODUCTION}

Animal food safety problems resulting from feeding antibiotics to animals, such as antibiotic residues and declining immunity, become increasingly severe (Aarnink and Verstegen, 2007), leading to the development of alternatives to antibiotics (including benzoic acid and thymol) (Mroz, 2005; Janczyk et al., 2009).

Benzoic acid, as a kind of organic acid, was authorized to be used in growing pigs at the dose of $0.5 \%$ to $1.0 \%$ by European Union in 2003. Certain research has proposed that benzoic acid can improve the growth performance and nutrients digestibility, inhibit pathogenic microorganisms, and maintain intestinal microecological balance (Kluge et

\footnotetext{
* Corresponding Author: Daiwen Chen. Tel: +86-0835-2882088, Fax: +86-0835-2885106, E-mail: dwchen@ sicau.edu.cn

${ }^{a}$ These authors contributed equally to this work.

Submitted Sept. 6, 2014; Revised Oct. 22, 2014; Accepted Dec. 22, 2014
}

al., 2006; Guggenbuhl et al., 2007; Torrallardona et al., 2007). Thymol, a plant essential oil, has been used in feed and food additives (Juven et al., 1994; Luna et al., 2010; Trevisi et al., 2010) as it has broad-spectrum antimicrobial properties in vitro (Klein et al., 2013), and can improve antioxidant ability.

Besides, in our former research, dietary $0.5 \%$ benzoic acid supplementation was found to increase growth performance and digestibility in weaned piglets (Diao et al., 2013). In addition, previous studies have reported that the combination of plant essential oils with organic acid produced a synergistic effect on antibacterial activity (Vondruskova et al., 2010; Giannenas et al., 2014). Therefore, substituting a portion of benzoic acid with thymol could save feeding costs. Thus, in regard to gut health, the mechanism of the effects of combining of benzoic acid and thymol need to be researched. The objective of this study was to evaluate the effects of different concentrations/ combinations of benzoic acid and 
thymol on growth performance, nutrient digestibility, digestive enzyme activity, digesta $\mathrm{pH}$ values, intestinal morphology, microbiota and microbial metabolites in weaned pigs.

\section{MATERIALS AND METHODS}

The experimental protocols were approved by the Sichuan Agricultural University Institutional Animal Care and Use Committee (Ya'an, China).

Benzoic acid (VevoVitall) and thymol were provided by DSM (China) Limited (476 Li Bing Road, Zhangjiang High Tech Park, Shanghai, Pudong New Area, China).

\section{Experimental design, animals, and housing}

A total of 144 healthy DLY ([YorkshirexLandrace]x Duroc) weaned piglets ( $24 \mathrm{~d}$ of age) with an initial average body weight $(\mathrm{BW})$ of $(6.03 \pm 0.78) \mathrm{kg}$ were allocated to 4 treatments with 6 replicates per treatment and 6 pigs per pen with randomized complete block design according to their initial BW and sex (3 gilts and 3 barrows/pen). Dietary treatment groups were: i) control (C), basal diet, ii) $\mathrm{C}+1,000 \mathrm{mg} / \mathrm{kg}$ benzoic acid $+100 \mathrm{mg} / \mathrm{kg}$ thymol (BT1), iii) $\mathrm{C}+1,000 \mathrm{mg} / \mathrm{kg}$ benzoic acid $+200 \mathrm{mg} / \mathrm{kg}$ thymol (BT2) and, iv) $\mathrm{C}+2,000 \mathrm{mg} / \mathrm{kg}$ benzoic acid $+100 \mathrm{mg} / \mathrm{kg}$ thymol (BT3). The whole trial was lasted for 42 days and was divided into two periods, days 1 to 14 and days 15 to 42 . On days 39 to 42 , the nutrient digestibility was measured using acid insoluble ash (AIA) as an endogenous indicator. The diets (barley-wheat-soybean-based diet) were manufactured in Sichuan Sanlian Feed Co., Ltd (Meishan, China). The diets were formulated to meet or exceed the NRC (1998) nutrient requirements for 5 to $10 \mathrm{~kg}$ and 10 to $20 \mathrm{~kg}$ piglets. Ingredients and compositions of the basic diets are presented in Table 1. Benzoic acid and thymol were included in the diet by substituting for the same amount of corn. No antibiotics were used in any diet. All pigs were housed in rooms with temperature maintained at $24^{\circ} \mathrm{C}$ to $26^{\circ} \mathrm{C}$, and relative humidity controlled at $60 \%$ to $70 \%$. Each pen $(1.3 \mathrm{~m} \times 1.2 \mathrm{~m})$ was equipped with a slatted plastic floor. Water and feed were provided ad libitum to piglets, and the lighting was natural.

\section{Sample collections and preparation}

Experimental diets were sampled and stored at $-20^{\circ} \mathrm{C}$ until analyzing dry matter (DM), crude protein (CP), calcium $(\mathrm{Ca})$, phosphorus $(\mathrm{P})$, ether extract (EE) and crude ash. Faecal samples were collected from d 39 to d 42 during the trial to determine the apparent total tract digestibility (ATTD) of DM, CP, Ca, P, EE, and crude ash. After each collection, $10 \%$ hydrochloric acid was added for fixation of excreta nitrogen. Faeces from 4 days of each replicate were mixed thoroughly and dried at $60^{\circ} \mathrm{C}$ for $72 \mathrm{~h}$, after which
Table 1. Ingredients and nutrient composition of basal diet during days 1 to 14 and days 15 to 42 (air dry basis) (\%) ${ }^{1}$

\begin{tabular}{|c|c|c|}
\hline Items & $\begin{array}{l}\text { Days } \\
1 \text { to } 14\end{array}$ & $\begin{array}{c}\text { Days } \\
15 \text { to } 42\end{array}$ \\
\hline \multicolumn{3}{|l|}{ Ingredients } \\
\hline Barley & 31.00 & 31.50 \\
\hline Wheat & 16.40 & 16.20 \\
\hline Maize (CP 7.8\%) & 14.23 & 18.36 \\
\hline Extruded soybean meal (CP 35.5\%) & 25.20 & 23.40 \\
\hline Whey powder (low protein) & 6.00 & 4.00 \\
\hline Fish meal (CP 60.2\%) & 5.50 & 5.40 \\
\hline$L$-Lys-HCl $(78 \%)$ & 0.28 & 0.12 \\
\hline$D L-\mathrm{Met}$ & 0.08 & 0.00 \\
\hline $\operatorname{Trp}(98 \%)$ & 0.04 & 0.01 \\
\hline $\operatorname{Thr}(98.5 \%)$ & 0.13 & 0.05 \\
\hline Choline chloride & 0.10 & 0.10 \\
\hline Dicalcium phosphate & 0.40 & 0.22 \\
\hline $\mathrm{NaCl}$ & 0.20 & 0.20 \\
\hline Vitamin complex ${ }^{2}$ & 0.04 & 0.04 \\
\hline Mineral complex ${ }^{3}$ & 0.40 & 0.40 \\
\hline Total & 100.00 & 100.00 \\
\hline \multicolumn{3}{|l|}{ Calculated composition } \\
\hline $\mathrm{DE}(\mathrm{MJ} / \mathrm{kg})$ & 14.29 & 14.29 \\
\hline $\mathrm{ME}(\mathrm{MJ} / \mathrm{kg})$ & 13.11 & 13.13 \\
\hline $\mathrm{CP}$ & 19.44 & 19.02 \\
\hline $\mathrm{Ca}$ & 0.82 & 0.74 \\
\hline Total phosphorus & 0.62 & 0.57 \\
\hline Available phosphorus & 0.42 & 0.36 \\
\hline Lys & 1.36 & 1.17 \\
\hline Met & 0.43 & 0.34 \\
\hline Thr & 0.91 & 0.80 \\
\hline Met+cys & 0.73 & 0.63 \\
\hline \multicolumn{3}{|l|}{ Analyzed composition } \\
\hline $\mathrm{CP}$ & 19.83 & 19.07 \\
\hline $\mathrm{Ca}$ & 0.76 & 0.59 \\
\hline Crude ash & 5.38 & 4.34 \\
\hline Ether extraction & 6.37 & 6.39 \\
\hline Dry matter & 88.75 & 88.71 \\
\hline Total energy (MJ/kg) & 18.70 & 18.67 \\
\hline Total phosphorus & 0.67 & 0.52 \\
\hline
\end{tabular}

$\mathrm{CP}$, crude protein; DE, digestible energy; ME, metabolizable energy.

${ }^{1}$ Analyzed acid insoluble ash (AIA) content of experimental diets (days 15 to 42 ) were: $0.34 \%, 0.38 \%, 0.39 \%, 0.37 \%$ respectively.

${ }^{2}$ The premix provides following per kg diet: Vitamin A 6,000 IU, Vitamin $\mathrm{D}_{3} 400 \mathrm{IU}$, Vitamin E $6.67 \mathrm{mg}$, Vitamin $\mathrm{K}_{3} 2 \mathrm{mg}$, Vitamin $\mathrm{B}_{1} 0.8 \mathrm{mg}$, Vitamin $B_{2} 6.4 \mathrm{mg}$, Vitamin $B_{6} 2.4 \mathrm{mg}$, Vitamin $B_{12} 12 \mu \mathrm{g}$, folic acid 0.2 $\mathrm{mg}$, nicotinic acid $14 \mathrm{mg}, D$-pantothenic acid $10 \mathrm{mg}$;

${ }^{3}$ The premix provides following per $\mathrm{kg}$ diet: $\mathrm{Fe}$ (as ferrous sulfate) 120 $\mathrm{mg}, \mathrm{Cu}$ (as copper sulfate) $6 \mathrm{mg}, \mathrm{Mn} 40 \mathrm{mg}, \mathrm{Zn}$ (as zinc sulfate) $100 \mathrm{mg}$, I $0.3 \mathrm{mg}$, Se $0.3 \mathrm{mg}$.

they were ground to pass through a 1-mm screen and stored at $-20^{\circ} \mathrm{C}$ for analyzing key nutrient contents.

At the end of d 14 and d 42, following fasted overnight, one piglet with the average $\mathrm{BW}$ in each pen was chosen and 
bled. Blood samples were collected from the precaval vein into nonheparinized vacuum tubes and centrifuged $(3,000 \times \mathrm{g})$ for $10 \mathrm{~min}$ at $4^{\circ} \mathrm{C}$. After bleeding, the pigs were fed and killed, and the time interval between beginning of feeding and euthanasia was $3 \mathrm{~h} \pm 20$ min on the sampling day. Two $\mathrm{mg} / \mathrm{kg}$ BW of chlorpromazine hydrochloride (Shanghai Harvest Pharmaceutical Co. Ltd. Shanghai, China) were used for euthanasia through intravenously injecting. Then, the tissues of duodenum, jejunum and ileum were immediately isolated, washed and preserved in $10 \%$ formalin solution. This was followed by measuring the $\mathrm{pH}$ of the digesta in the duodenum, jejunum, ileum, caecum and colon. Additionally, digesta from jejunum, ileum and caecum were collected and stored at $-80^{\circ} \mathrm{C}$ for measuring digestive enzymes activities, microbial quantity and microbial metabolites.

\section{Growth performance}

Individual pig BW was recorded at d 0, d 14, and d 42 of the experimental period, and weighing was performed before pigs were fed. Feed consumption was recorded as the amount of feed offered daily minus the remaining quantity in the feeder next morning on a pen basis during the experiment. These values were used to calculate average daily gain, average daily feed intake, and ratio of feed to gain $(\mathrm{F} / \mathrm{G})$.

\section{Diarrhoea scores}

Pen diarrhoea scores were recorded every morning and evening for 42 days of the trial based on the following scoring system: $0=$ no diarrhoea, $1=$ diarrhoea less than $20 \%$ of pigs, $2=$ diarrhoea in $20 \%$ to $40 \%$ of pigs, $3=$ diarrhoea more than $40 \%$ of pigs. Pen diarrhoea scores were measured by the same person throughout the trial period, and the person was blinded to treatment groups. The final diarrhoea scores $=$ the sum of pen diarrhoea scores recorded in the morning and evening in each treatment during 42 $\mathrm{d} /$ replicates.

\section{Serum physiochemical parameters}

Serum albumin, cholesterol, triglyceride, urea, globulin, $\mathrm{Ca}$, $\mathrm{P}$, total protein, thyroxine, triiodothyronine were determined using an automatic biochemistry analyzer (PUZS-300, Perlong, Beijing, China).

\section{Apparent total tract digestibility}

The ATTD was measured using AIA as indicator. The AIA in diets and faeces samples was determined by a method described by Chinese National Standard (GB/T 23742). All feed and faecal samples were analyzed for DM (method 930.15, AOAC, 1995), crude ash (method 942.05, AOAC, 1995), EE (method 945.16, AOAC, 1995), Ca (method 927.02, AOAC, 1995), P (method 995.11, AOAC,
1995), and CP (method 990.03, AOAC, 1995). The ATTD was calculated as $(100-\mathrm{A} 1 \mathrm{~F} 2 / \mathrm{A} 2 \mathrm{~F} 1 \times 100)$, where A1 represents the AIA content of the diet; A2 represents the AIA content of faeces; F1 represents the nutrient content of the diet; F2 represents the nutrient content of faeces.

\section{Digestive enzyme activity and $\mathrm{pH}$ values of digesta}

Digestive enzyme activity in frozen jejunal digesta was determined by commercial kits (Nanjing Jiancheng Bioengineering Institute, Nanjing, China). Briefly, the samples were homogenized after dilution with saline (1:9), followed by centrifuging at 2,000×g for $10 \mathrm{~min}$, and the aliquots were stored at $-80^{\circ} \mathrm{C}$ for assay of enzyme activities. Then trypsin, lipase, amylase, lactase, sucrase and maltase activities were determined using commercial kits combined with UV-VIS Spectrophotometer (UV1100, MAPADA, Shanghai, China) according to the manufacturer's instructions. The $\mathrm{pH}$ values of digesta were measured with a pH meter (PHS-3C pH, Shanghai, China) on d 14 and d 42.

\section{Enumeration of Eschericha coli, Lactobacillus spp, Bifidobacterium spp, Bacillus spp, and total bacteria}

Bacterial DNA was isolated from the frozen ileal and caecal digesta samples using an EZNATM stool DNA extraction kit (Omega BioTek, Doraville, CA, USA) according to the manufacturer's instructions. Primers and probes (Table 2) for total bacteria, Eschericha coli, Lactobacillus spp, Bifidobacterium spp, and Bacillus spp were obtained from the published work of Fierer et al. (2005) and Qi et al. (2011), and commercially synthesized by Invitrogen (Shanghai, China). Quantitative real-time polymerase chain reaction (PCR) was conducted to quantify total bacteria, Eschericha coli, Lactobacillus spp, Bifidobacterium spp, and Bacillus spp with IQ5 real-time PCR detection System (Bio-Rad, Richmond, CA, USA) as previously described by Qi et al. (2011).

\section{Short chain fatty acids}

Short chain fatty acids (SCFAs; acetic acid, propionic acid, and butyric acid) were separated and quantified from the frozen caecal digesta samples in a gas chromatographic system (VARIAN CP-3800, Varian, Palo Alto, CA, USA) as previously described by Chen et al. (2013).

\section{Ammonia nitrogen $\left(\mathrm{NH}_{3}-\mathrm{N}\right)$}

The ceacal digesta samples were centrifuged at 5,000 $\times g$ for $15 \mathrm{~min}$ after adding 1:10 ammonia-free water and mixing on a vortex mixer. One $\mathrm{mL}$ supernatant was transferred to a sterile tube, then $49 \mathrm{~mL}$ ammonia-free water was added, followed by adding $1 \mathrm{~mL}$ potassium sodium tartrate solution and briefly mixed on a vortex mixer. Then, $1.5 \mathrm{~mL}$ Nessler's reagent was added, mixed and incubated at room temperature for $10 \mathrm{~min}$. The absorbance was read at 
Table 2. Primers and probes for real time polymerase chain reaction

\begin{tabular}{llc}
\hline Items & \multicolumn{1}{c}{ Primer/probe name and sequence (5'-3') } & Product ength/bp \\
\hline Lactobacillus spp & RS-F,GAGGCAGCAGTAGGGAATCTTC & 126 \\
& RS-R,CAACAGTTACTCTGACACCCGTTCTTC & \\
& RS-P,(Hildebrandt et al.)AAGAAGGGTTTCGGCTCGTAAAACTCTGTT(BHQ-1) & 96 \\
Eschericha coli & DC-F,CATGCCGCGTGTATGAAGAA & 121 \\
& DC-R,CGGGTAACGTCAATGAGCAAA & \\
& DC-P,(Hildebrandt et al.)AGGTATTAACTTTACTCCCTTCCTC(BHQ-1) & 92 \\
Bacillus spp & SQ-F,CGCGTCCGGTGTGAAG & \\
& SQ-R,CTTCCCGATATCTACACATTCCA & \\
Total bacteria & SQ-P, (Hildebrandt et al.) ATTCCACCGTTACACCGGGAA(BHQ-1) & 200 \\
& YB-F,GCAACGAGCGCAACCCTTGA & \\
\hline
\end{tabular}

$420 \mathrm{~nm}$ against ammonia-free water on a UV-VIS Spectrophotometer (UV1100, MAPADA, Shanghai, China), and $\mathrm{NH}_{3}-\mathrm{N}$ concentrations were measured and calculated from absorbance of standards. The content of $\mathrm{NH}_{3}-\mathrm{N}$ was calculated as $(\mathrm{m} \times 1,000 / \mathrm{V})$, where $\mathrm{m}$ represents the $\mathrm{NH}_{3}-\mathrm{N}$ content corrected by standard curve and $\mathrm{V}$ represents the volume of supernatant.

\section{Morphology}

The ring-shaped histological sections of duodenum, jejunum and ileum were excised, dehydrated, and embedded in paraffin wax before 4 transverse sections (5 $\mu \mathrm{m})$ were cut, and then installed on glass slides and stained with haematoxylin and eosin. The height of 10 well orientated villi and their adjoined crypts were measured with a light microscope using a calibrated eyepiece graticule and a computer-assisted, image-analysis system (Pluske et al., 1996).

\section{Statistical analysis}

Statistical analysis was performed for all experimental data that were subjected to analysis of variance (ANOVA) in the statistical program of SAS version 8.2 (SAS Inst. Inc., Cary, NC, USA) where pen was the statistical unit. When a significant $p$-value $(p<0.05$ or $p<0.10)$ was observed in ANOVA, means of dietary treatments were compared using Duncan's multiple comparison, whereas $\mathrm{p}<0.10$ was considered a tendency. All data are presented as means with pooled standard error of the mean.

\section{RESULTS}

Effects of benzoic acid and thymol on growth performance and diarrhoea in piglets

From d 0 to 14, F/G was decreased in pigs fed BT3 diet compared to diet treatment $\mathrm{C}$ (Table $3 ; \mathrm{p}<0.05)$, and no differences were observed in BT1, BT2, and BT3 diets for the F/G. There was a tendency to decreased F/G during the overall period ( 1 to 42 ) in pigs fed BT3 diet compared to diet treatment $C(p<0.10)$, and no differences were observed in BT1, BT2, and BT3 diets for the F/G during the overall period. Pigs fed the BT1, BT2, and BT3 diets tended to have lower diarrhoea scores compared to diet treatment $\mathrm{C}$, and pigs fed the BT3 diet tended to have lower diarrhoea scores compared to diet treatment BT1 and BT2, and there were no differences between diet treatment BT1 and BT2 for diarrhoea $(\mathrm{p}<0.10)$.

Table 3. Effects of benzoic acid and thymol on growth performance and diarrhoea in piglets

\begin{tabular}{|c|c|c|c|c|c|c|}
\hline \multirow{2}{*}{ Item } & \multicolumn{4}{|c|}{ Treatment $^{1}$} & \multirow{2}{*}{ SEM } & \multirow{2}{*}{ p-values } \\
\hline & $\mathrm{C}$ & BT1 & BT2 & BT3 & & \\
\hline \multicolumn{7}{|l|}{1 to $14 \mathrm{~d}$} \\
\hline ADFI (g) & 225 & 250 & 232 & 226 & 16.4 & 0.70 \\
\hline $\mathrm{ADG}(\mathrm{g})$ & 151 & 178 & 162 & 173 & 15.4 & 0.63 \\
\hline $\mathrm{F} / \mathrm{G}$ & $1.51^{\mathrm{a}}$ & $1.42^{\mathrm{ab}}$ & $1.45^{\mathrm{ab}}$ & $1.31^{\mathrm{b}}$ & 0.03 & 0.04 \\
\hline \multicolumn{7}{|l|}{15 to $42 \mathrm{~d}$} \\
\hline ADFI (g) & 651 & 629 & 597 & 625 & 19.4 & 0.20 \\
\hline $\mathrm{ADG}(\mathrm{g})$ & 396 & 392 & 370 & 342 & 13.1 & 0.15 \\
\hline F/G & 1.64 & 1.6 & 1.61 & 1.58 & 0.03 & 0.47 \\
\hline \multicolumn{7}{|l|}{1 to $42 \mathrm{~d}$} \\
\hline ADFI (g) & 509 & 503 & 475 & 492 & 14.4 & 0.41 \\
\hline ADG (g) & 314 & 320 & 301 & 322 & 9.62 & 0.42 \\
\hline $\mathrm{F} / \mathrm{G}$ & $1.62^{\mathrm{a}}$ & $1.57^{\mathrm{ab}}$ & $1.58^{\mathrm{ab}}$ & $1.53^{\mathrm{b}}$ & 0.02 & 0.09 \\
\hline Diarrhoea score & $30.0^{\mathrm{a}}$ & $12.3^{b c}$ & $17.2^{\mathrm{b}}$ & $7.67^{\mathrm{c}}$ & 5.80 & 0.08 \\
\hline
\end{tabular}

SEM, standard error of the mean $(n=6$, number of replicates); ADFI, average daily feed intake; $\mathrm{ADG}$, average daily gain; F/G, ratio of feed to gain.

${ }^{1} \mathrm{C}$, control, basal diet; BT1, C+1,000 mg/kg benzoic acid $+100 \mathrm{mg} / \mathrm{kg}$ thymol; BT2, C+1,000 mg/kg benzoic acid $+200 \mathrm{mg} / \mathrm{kg}$ thymol; BT3, $\mathrm{C}+2,000 \mathrm{mg} / \mathrm{kg}$ benzoic acid $+100 \mathrm{mg} / \mathrm{kg}$ thymol.

${ }^{a-c}$ Within a row, means without a common superscrip, differ $(\mathrm{p}<0.05$ or $\mathrm{p}<0.10)$. 
Effects of benzoic acid and thymol on serum physiochemical parameter in piglets

On d 14, serum albumin, triglyceride, cholesterol, globulin, urea, total protein, $\mathrm{Ca}$, triiodothyronine and thyroxine were not affected by dietary treatments (Table 4), and there was a tendency to increase P in pigs fed the BT1, $\mathrm{BT} 2$, and BT3 diets compared to diet treatment $\mathrm{C}$, and no differences were observed in BT1, BT2, and BT3 diets for the content of serum $\mathrm{P}(\mathrm{p}<0.10)$. On $\mathrm{d} 42$, serum albumin, triglyceride, cholesterol, globulin, urea, total protein, $\mathrm{P}$, triiodothyronine and thyroxine were not affected by dietary treatments, and the serum content of $\mathrm{Ca}$ in pigs fed the BT2 and BT3 diets was greater than that in pigs fed $\mathrm{C}$ diet, and there were no differences among BT1, BT2, and BT3 diets for the serum content of $\mathrm{Ca}(\mathrm{p}<0.05)$.

\section{Effects of benzoic acid and thymol on nutrients digestibility in piglets}

The ATTD of EE $(p<0.05)$ and CP $(p<0.10)$ in pigs fed the BT2 and BT3 diets was greater than that in pigs fed the $\mathrm{C}$ diet, and there were no differences among BT1, BT2, and BT3 diets for the ATTD of EE and CP (Table 5). Pigs fed the BT3 diet had greater ATTD of $\mathrm{Ca}(\mathrm{p}<0.05)$ and crude ash $(\mathrm{p}<0.05)$ compared with pigs fed the $\mathrm{C}$ diet, and no differences were observed in BT1, BT2, and BT3 diets for
Table 5. Effects of benzoic acid and thymol on nutrient digestibility in piglets $(\%)$

\begin{tabular}{lcccccc}
\hline $\begin{array}{c}\text { Item } \\
\text { (g/kg) }\end{array}$ & $\mathrm{C}$ & BT1 & BT2 & BT3 & SEM & p-values \\
\cline { 2 - 6 } CP & $82.3^{\mathrm{b}}$ & $84.1^{\mathrm{ab}}$ & $84.2^{\mathrm{a}}$ & $84.7^{\mathrm{a}}$ & 0.63 & 0.07 \\
$\mathrm{DM}$ & 86.3 & 86.2 & 85.9 & 86.2 & 0.36 & 0.84 \\
$\mathrm{EE}$ & $79.7^{\mathrm{b}}$ & $80.8^{\mathrm{ab}}$ & $82.8^{\mathrm{a}}$ & $82.8^{\mathrm{a}}$ & 0.77 & 0.03 \\
$\mathrm{Ca}$ & $59.7^{\mathrm{b}}$ & $65.5^{\mathrm{ab}}$ & $65.1^{\mathrm{ab}}$ & $66.7^{\mathrm{a}}$ & 1.61 & 0.03 \\
$\mathrm{P}$ & 44.7 & 51.0 & 50.5 & 51.4 & 2.18 & 0.14 \\
Crude ash & $53.3^{\mathrm{b}}$ & $54.7^{\mathrm{ab}}$ & $56.7^{\mathrm{ab}}$ & $57.3^{\mathrm{a}}$ & 0.93 & 0.03 \\
\hline SEM, standard error of the mean $(\mathrm{n}=6$, number of replicates) $\mathrm{DM}, \mathrm{dry}$ \\
matter; CP, crude protein; EE, ether extract; Ca, calcium; P, phosphorus. \\
${ }^{1} \mathrm{C}$, control, basal diet; BT1, C+1,000 mg/kg benzoic acid+100 mg/kg \\
thymol; BT2, C+1,000 mg/kg benzoic acid+200 mg/kg thymol; BT3, \\
C+2,000 mg/kg benzoic acid+100 mg/kg thymol. \\
a-b Within a row, means without a common superscript differ (p<0.05 or \\
p<0.10).
\end{tabular}

the ATTD of $\mathrm{Ca}$ and crude ash.

\section{Effects of benzoic acid and thymol on digestive enzyme activity in jejunum of piglets}

On d 14, pigs fed the BT3 diet had a greater activity of trypsin compared with pigs fed the $\mathrm{C}$ diet (Table $6 ; \mathrm{p}<0.05$ ), and pigs fed the BT1, BT2, and BT3 diets had greater activities of lipase, amylase, maltase and lactase compared

Table 4. Effects of benzoic acid and thymol on serum physiochemical parameters in piglets

\begin{tabular}{|c|c|c|c|c|c|c|}
\hline \multirow{2}{*}{ Item } & \multicolumn{4}{|c|}{ Treatment $^{1}$} & \multirow{2}{*}{ SEM } & \multirow{2}{*}{ p-value } \\
\hline & $\mathrm{C}$ & BT1 & BT2 & BT3 & & \\
\hline \multicolumn{7}{|l|}{$14 \mathrm{~d}$} \\
\hline Albumin (g/L) & 30.2 & 33.1 & 32.2 & 33.1 & 1.07 & 0.22 \\
\hline Cholesterol (mmol/mL) & 2.20 & 2.15 & 2.13 & 1.88 & 0.11 & 0.19 \\
\hline Triglyceride $(\mathrm{mmol} / \mathrm{mL})$ & 0.57 & 0.53 & 0.56 & 0.56 & 0.07 & 0.97 \\
\hline Urea (mg/dL) & 3.16 & 3.04 & 2.94 & 2.90 & 0.24 & 0.86 \\
\hline Globulin (g/L) & 20.5 & 22.6 & 25.9 & 26.0 & 2.74 & 0.43 \\
\hline $\mathrm{P}(\mathrm{mmol} / \mathrm{mL})$ & $2.74^{\mathrm{b}}$ & $3.09^{\mathrm{a}}$ & $3.04^{\mathrm{a}}$ & $3.09^{\mathrm{a}}$ & 0.10 & 0.08 \\
\hline $\mathrm{Ca}(\mathrm{mmol} / \mathrm{mL})$ & 2.36 & 2.43 & 2.40 & 2.48 & 0.06 & 0.61 \\
\hline Total protein $(\mathrm{g} / \mathrm{L})$ & 50.7 & 55.7 & 58.1 & 59.1 & 2.86 & 0.20 \\
\hline Thyroxine (ng/mL) & 63.5 & 64.8 & 69.5 & 73.6 & 9.46 & 0.87 \\
\hline Triiodothyronine $(\mathrm{ng} / \mathrm{mL})$ & 1.59 & 1.76 & 1.71 & 1.98 & 0.21 & 0.61 \\
\hline \multicolumn{7}{|l|}{$42 \mathrm{~d}$} \\
\hline Albumin $(\mathrm{g} / \mathrm{L})$ & 32.0 & 32.9 & 33.9 & 34.1 & 1.05 & 0.48 \\
\hline Cholesterol (mmol/mL) & 2.34 & 2.17 & 2.22 & 2.13 & 0.17 & 0.82 \\
\hline Triglyceride (mmol/mL) & 0.63 & 0.60 & 0.59 & 0.43 & 0.06 & 0.10 \\
\hline Urea (mg/dL) & 3.80 & 3.03 & 3.41 & 2.72 & 0.48 & 0.44 \\
\hline Globulin $(\mathrm{g} / \mathrm{L})$ & 25.3 & 26.4 & 26.8 & 26.4 & 1.60 & 0.91 \\
\hline $\mathrm{P}(\mathrm{mmol} / \mathrm{mL})$ & 3.41 & 3.56 & 3.57 & 3.55 & 0.07 & 0.41 \\
\hline $\mathrm{Ca}(\mathrm{mmol} / \mathrm{mL})$ & $2.27^{\mathrm{b}}$ & $2.46^{\mathrm{ab}}$ & $2.49^{\mathrm{a}}$ & $2.48^{\mathrm{a}}$ & 0.05 & 0.03 \\
\hline Total protein $(\mathrm{g} / \mathrm{L})$ & 28.8 & 29.9 & 30.3 & 29.9 & 1.60 & 0.91 \\
\hline Thyroxine (ng/mL) & 80.3 & 79.9 & 79.5 & 82.1 & 5.39 & 0.99 \\
\hline Triiodothyronine (ng/mL) & 2.00 & 2.17 & 2.14 & 2.34 & 0.12 & 0.30 \\
\hline
\end{tabular}

SEM, standard error of the mean ( $\mathrm{n}=6$, number of replicates).

${ }^{1} \mathrm{C}$, control, basal diet; BT1, C+1,000 mg/kg benzoic acid+100 mg/kg thymol; BT2, C+1,000 mg/kg benzoic acid+200 mg/kg thymol; BT3, C+2,000 $\mathrm{mg} / \mathrm{kg}$ benzoic acid $+100 \mathrm{mg} / \mathrm{kg}$ thymol.

${ }^{\mathrm{a}-\mathrm{b}}$ Within a row, means without a common superscript differ $(\mathrm{p}<0.05$ or $\mathrm{p}<0.10)$. 
Table 6. Effects of benzoic acid and thymol on digestive enzyme activity in jejunum of piglets

\begin{tabular}{|c|c|c|c|c|c|c|}
\hline \multirow{2}{*}{ Item } & \multicolumn{4}{|c|}{ Treatment $^{1}$} & \multirow{2}{*}{ SEM } & \multirow{2}{*}{ p-values } \\
\hline & $\mathrm{C}$ & BT1 & BT2 & BT3 & & \\
\hline \multicolumn{7}{|l|}{$\overline{14 d}$} \\
\hline Trypsin (U·103/mg pro) & $42.7^{\mathrm{b}}$ & $60.2^{\mathrm{ab}}$ & $54.4^{\mathrm{ab}}$ & $65.0^{\mathrm{a}}$ & 4.93 & 0.03 \\
\hline Amylase (U/mg pro) & $293^{\mathrm{b}}$ & $375^{\mathrm{a}}$ & $358^{\mathrm{a}}$ & $377^{\mathrm{a}}$ & 13.87 & $<0.01$ \\
\hline Lipase (U. $10^{3} / \mathrm{g}$ pro) & $1.25^{\mathrm{b}}$ & $1.99^{\mathrm{a}}$ & $2.18^{\mathrm{a}}$ & $2.19^{\mathrm{a}}$ & 0.09 & $<0.01$ \\
\hline Maltase (U. $10^{3} / \mathrm{mg}$ pro) & $0.81^{\mathrm{b}}$ & $1.02^{\mathrm{a}}$ & $1.02^{\mathrm{a}}$ & $1.15^{\mathrm{a}}$ & 0.05 & $<0.01$ \\
\hline Lactase (U/mg pro) & $33.8^{\mathrm{d}}$ & $68.0^{\mathrm{b}}$ & $59.9^{\mathrm{c}}$ & $88.8^{\mathrm{a}}$ & 4.89 & $<0.01$ \\
\hline Sucrase (U/mg pro) & $82.8^{\mathrm{b}}$ & $99.4^{\mathrm{b}}$ & $90.7^{\mathrm{b}}$ & $177^{\mathrm{a}}$ & 10.8 & $<0.01$ \\
\hline \multicolumn{7}{|l|}{$42 \mathrm{~d}$} \\
\hline Trypsin $\left(\mathrm{U} \cdot 10^{3} / \mathrm{mg}\right.$ pro $)$ & 39.2 & 47.0 & 46.1 & 48.2 & 4.82 & 0.57 \\
\hline Amylase (U/mg pro) & 301 & 369 & 346 & 373 & 28.0 & 0.29 \\
\hline Lipase $\left(\mathrm{U} \cdot 10^{3} / \mathrm{g}\right.$ pro) & $2.16^{\mathrm{b}}$ & $2.56^{\mathrm{ab}}$ & $2.64^{\mathrm{ab}}$ & $2.76^{\mathrm{a}}$ & 0.14 & 0.04 \\
\hline Maltase $\left(\mathrm{U} \cdot 10^{3} / \mathrm{mg}\right.$ pro) & 0.39 & 0.43 & 0.41 & 0.45 & 0.06 & 0.90 \\
\hline Lactase (U/mg pro) & $32.8^{\mathrm{d}}$ & $46.0^{\mathrm{b}}$ & $41.0^{\mathrm{c}}$ & $62.9^{\mathrm{a}}$ & 2.03 & $<0.01$ \\
\hline Sucrase (U/mg pro) & $110^{\mathrm{b}}$ & $147^{\mathrm{b}}$ & $126^{\mathrm{b}}$ & $233^{\mathrm{a}}$ & 18.3 & $<0.01$ \\
\hline
\end{tabular}

SEM, standard error of the mean ( $\mathrm{n}=6$, number of replicates).

${ }^{1} \mathrm{C}$, control, basal diet; BT1, C+1,000 mg/kg benzoic acid+100 mg/kg thymol; BT2, C+1,000 mg/kg benzoic acid+200 mg/kg thymol; BT3, C+2,000 $\mathrm{mg} / \mathrm{kg}$ benzoic acid+100 $\mathrm{mg} / \mathrm{kg}$ thymol.

${ }^{\mathrm{a}-\mathrm{d}}$ Within a row, means without a common superscript differ $(\mathrm{p}<0.05$ or $\mathrm{p}<0.10)$.

with pigs fed the $\mathrm{C}$ diet, and the activity of lactase in pigs fed the BT3 diet was greater than that in pigs fed the BT1 and BT2 diets, and the activity of lactase in pigs fed the BT1 diet was greater than that in pigs fed the BT2 diet ( $\mathrm{p}<$ 0.05 ), and the activity of sucrase in pigs fed the BT3 diet was greater than that in pigs fed the C, BT1, and BT2 diets, and the activity of sucrase in pigs fed the BT1 and BT2 diets were greater than that in pigs fed the $C$ diet $(p<0.05)$. On $\mathrm{d} 42$, pigs fed the BT3 diet had greater activity of lipase compared with pigs fed the $\mathrm{C}$ diet $(\mathrm{p}<0.05)$, and the activity of lactase in pigs fed the BT1, BT2, and BT3 diets was greater than that in pigs fed $\mathrm{C}$ diet, and the activity of lactase in pigs fed the BT3 diet was greater than that in pigs fed the BT1 and BT2 diets, and the activity of lactase in pigs fed the BT1 diet was greater than that in pigs fed the BT2 diet $(\mathrm{p}<0.05)$, and pigs fed the BT3 diet had greater activity of sucrase compared with pigs fed the C, BT1, and BT2 diets $(\mathrm{p}<0.05)$.

\section{Effects of benzoic acid and thymol on pH values of the digesta of piglets}

There were no differences in $\mathrm{pH}$ values of the digesta in jejunum, ileum and caecum on $\mathrm{d} 14$ and in the duodenum, jejunum, ileum and caecum on d 42 among dietary treatments (Table 7). However, pigs fed the BT1, BT2, and BT3 diets tended to had lower $\mathrm{pH}$ values of the digesta in the colon on d 14 compared to diet treatment $\mathrm{C}$, and there were no differences among diet treatment BT1, BT2, and BT3 for the $\mathrm{pH}$ values of the digesta in the colon on $\mathrm{d} 14$ $(\mathrm{p}<0.10)$, and pigs fed the BT3 diet tended to had lower $\mathrm{pH}$ values of the digesta in the colon on $\mathrm{d} 42$ compared to diet treatment $\mathrm{C}$, and no differences were observed in diet treatment BT1, BT2, and BT3 for the $\mathrm{pH}$ values of the digesta in the colon on $\mathrm{d} 42(\mathrm{p}<0.10)$.

Effects of benzoic acid and thymol on total bacteria, Eschericha coli, Lactobacillus spp, Bifidobacterium spp, and Bacillus spp. in ileal and caecal digesta of piglets

The population of Lactobacillus spp in ileal digesta of pigs fed the BT3 diet was greater than that of pigs fed C diet on d 14, and no differences were observed in BT1, BT2, and BT3 diets for the population of Lactobacillus spp in ileal digesta (Table $8 ; \mathrm{p}<0.05$ ). Pigs fed the BT1, BT2, and

Table 7. Effects of benzoic acid and thymol on $\mathrm{pH}$ values of the digesta of piglets

\begin{tabular}{|c|c|c|c|c|c|c|}
\hline \multirow{2}{*}{ Item } & \multicolumn{4}{|c|}{ Treatment } & \multirow{2}{*}{ SEM } & \multirow{2}{*}{ p-values } \\
\hline & $\mathrm{C}$ & BT1 & BT2 & BT3 & & \\
\hline \multicolumn{7}{|l|}{$14 \mathrm{~d}$} \\
\hline Jejunum & 6.23 & 6.00 & 6.23 & 6.12 & 0.30 & 0.93 \\
\hline Ileum & 6.93 & 6.74 & 6.69 & 6.50 & 0.14 & 0.24 \\
\hline Caecum & 5.98 & 5.91 & 5.80 & 5.56 & 0.16 & 0.32 \\
\hline Colon & $6.35^{\mathrm{a}}$ & $5.84^{\mathrm{b}}$ & $5.87^{\mathrm{b}}$ & $5.83^{\mathrm{b}}$ & 0.15 & 0.07 \\
\hline \multicolumn{7}{|l|}{$42 \mathrm{~d}$} \\
\hline Duodenum & 5.04 & 4.99 & 4.91 & 4.83 & 0.13 & 0.67 \\
\hline Jejunum & 6.40 & 6.10 & 6.24 & 6.21 & 0.17 & 0.65 \\
\hline Ileum & 6.77 & 6.77 & 6.72 & 6.53 & 0.23 & 0.87 \\
\hline Caecum & 5.74 & 5.60 & 5.76 & 5.43 & 0.17 & 0.50 \\
\hline Colon & $6.85^{\mathrm{a}}$ & $6.72^{\mathrm{ab}}$ & $6.66^{\mathrm{ab}}$ & $6.35^{\mathrm{b}}$ & 0.12 & 0.07 \\
\hline
\end{tabular}

SEM, standard error of the mean ( $n=6$, number of replicates).

${ }^{1} \mathrm{C}$, control, basal diet; BT1, C+1,000 mg/kg benzoic acid+100 mg/kg thymol; BT2, C+1,000 mg/kg benzoic acid+200 mg/kg thymol; BT3, $\mathrm{C}+2,000 \mathrm{mg} / \mathrm{kg}$ benzoic acid+100 $\mathrm{mg} / \mathrm{kg}$ thymol.

${ }^{a-b}$ Within a row, means without a common superscript differ $(\mathrm{p}<0.05$ or $\mathrm{p}<0.10)$. 
BT3 diet had a greater population of Bacillus spp in digesta of caecum compared to pigs fed the $\mathrm{C}$ diet on $\mathrm{d} 14$, and there were no differences among BT1, BT2, and BT3 diets for the populations of Bacillus spp in digesta of caecum $(\mathrm{p}<0.05)$. The population of Eschericha coli in caecal digesta of pigs fed the BT2 diet and both in ileal and caecal digesta of pigs fed the BT1 diet was lower than that of pigs fed the $\mathrm{C}$ diet on $\mathrm{d} 42$, and the population of Eschericha coli in caecal digesta of pigs fed the BT2 diet was lower than that of pigs fed the BT3 diet on $\mathrm{d} 42$, and no differences were observed in the population of Eschericha coli in caecal digesta of pigs fed BT1 and BT3 diets ( $\mathrm{p}<$ 0.05). There was a tendency for the population of Bifidobacterium spp to increase in digesta of caecum of pigs fed the BT1, BT2, and BT3 diets on the $\mathrm{d} 14$ compared to diet treatment $C(\mathrm{p}<0.10)$.

Effects of benzoic acid and thymol on microbial metabolites in caecal digesta of piglets

There was a tendency for the concentration of total volatile fatty acid to increase in caecal digesta of pigs fed the BT3 diet compared to diet treatment C, BT1, and BT2 on d 14, and there were no differences between BT1 and BT2 diets for the concentration of total volatile fatty acid in caecal digesta (Table 9; $<<0.10$ ), and the concentration of butyric acid in caecal digesta of pigs fed the BT3 diet was greater than that of pigs fed the C and BT2 diets on $\mathrm{d} 42$, and no differences were observed between BT1 and BT3 diets for the concentration of butyric acid $(p<0.05)$. The concentration of $\mathrm{NH}_{3}-\mathrm{N}$ in caecal digesta of pigs fed the $\mathrm{C}$ diet was higher than that of pigs fed the BT1, BT2, and BT3 diets on $\mathrm{d} 14$ and d $42(\mathrm{p}<0.05)$.

\section{Effects of benzoic acid and thymol on morphology of the small intestine of piglets}

On $\mathrm{d} 14$, the villous height to crypt depth ratio in jejunum and ileum for pigs fed BT3 diet and in ileum of pigs fed BT1 and BT2 diets was greater than those of pigs fed $\mathrm{C}$ diet, and the villous height to crypt depth ratio in ileum for pigs fed BT3 die was greater than that of pigs fed BT1 and BT2 diets (Table 10; p<0.05), and there was a tendency to increase the villous height in jejunum and ileum of pigs fed the BT3 diet compared to diet treatment $\mathrm{C}$ and BT2, and no differences were observed in BTI and BT2

Table 8. Effects of benzoic acid and thymol on ileal and caecal E. coli, lactobacilli, Bifidobacterium spp. and Bacillus spp. of piglets, quantitative polymerase chain reaction results $(\log [\mathrm{copies} / \mathrm{g}])$

\begin{tabular}{|c|c|c|c|c|c|c|}
\hline \multirow{2}{*}{ Item } & \multicolumn{4}{|c|}{ Treatment $^{1}$} & \multirow{2}{*}{ SEM } & \multirow{2}{*}{ p-values } \\
\hline & $\mathrm{C}$ & BT1 & BT2 & BT3 & & \\
\hline \multicolumn{7}{|l|}{$14 \mathrm{~d}$ ileum } \\
\hline Total bacteria & 9.41 & 9.66 & 9.41 & 9.86 & 0.22 & 0.44 \\
\hline Lactobacillus spp & $6.80^{\mathrm{b}}$ & $7.88^{\mathrm{ab}}$ & $7.54^{\mathrm{ab}}$ & $8.53^{\mathrm{a}}$ & 0.38 & 0.04 \\
\hline Bifidobacterium spp & 7.13 & 7.39 & 7.14 & 7.63 & 0.17 & 0.18 \\
\hline Bacillus spp & 8.82 & 9.26 & 8.99 & 9.41 & 0.22 & 0.26 \\
\hline Eschericha coli & 9.60 & 8.70 & 8.62 & 8.48 & 0.53 & 0.47 \\
\hline \multicolumn{7}{|l|}{$14 \mathrm{~d}$ caecum } \\
\hline Total bacteria & 11.1 & 11.0 & 10.8 & 11.0 & 0.17 & 0.56 \\
\hline Lactobacillus spp & 8.47 & 8.75 & 8.63 & 8.74 & 0.18 & 0.67 \\
\hline Bifidobacterium spp & $6.97^{\mathrm{b}}$ & $7.44^{\mathrm{a}}$ & $7.88^{\mathrm{a}}$ & $7.30^{\mathrm{a}}$ & 0.22 & 0.06 \\
\hline Bacillus spp & $9.06^{\mathrm{b}}$ & $9.98^{\mathrm{a}}$ & $9.95^{\mathrm{a}}$ & $9.78^{\mathrm{a}}$ & 0.18 & $<0.01$ \\
\hline Eschericha coli & 9.05 & 9.07 & 9.30 & 8.94 & 0.45 & 0.95 \\
\hline \multicolumn{7}{|l|}{$42 \mathrm{~d}$ ileum } \\
\hline Total bacteria & 9.55 & 9.81 & 9.60 & 9.88 & 0.22 & 0.66 \\
\hline Lactobacillus spp & 7.20 & 7.88 & 7.64 & 7.89 & 0.47 & 0.71 \\
\hline Bifidobacterium spp & 7.93 & 8.01 & 7.71 & 7.79 & 0.15 & 0.50 \\
\hline Bacillus spp & 8.93 & 9.43 & 9.07 & 9.52 & 0.25 & 0.31 \\
\hline Eschericha coli & $9.15^{\mathrm{a}}$ & $7.71^{\mathrm{b}}$ & $7.56^{\mathrm{b}}$ & $7.85^{\mathrm{ab}}$ & 0.34 & 0.02 \\
\hline \multicolumn{7}{|l|}{$42 \mathrm{~d}$ caecum } \\
\hline Total bacteria & 11.5 & 11.5 & 11.4 & 11.3 & 0.10 & 0.72 \\
\hline Lactobacillus spp & 8.57 & 8.92 & 8.78 & 8.53 & 0.14 & 0.22 \\
\hline Bifidobacterium spp & 7.93 & 8.11 & 7.61 & 7.50 & 0.27 & 0.39 \\
\hline Bacillus spp & 9.60 & 9.83 & 9.60 & 9.76 & 0.11 & 0.35 \\
\hline Eschericha coli & $8.56^{\mathrm{a}}$ & $7.77^{\mathrm{ab}}$ & $7.55^{\mathrm{b}}$ & $7.91^{\mathrm{a}}$ & 0.23 & 0.04 \\
\hline
\end{tabular}

SEM, standard error of the mean ( $n=6$, number of replicates).

${ }^{1} \mathrm{C}$, control, basal diet; BT1, C+1,000 mg/kg benzoic acid+100 mg/kg thymol; BT2, C+1,000 mg/kg benzoic acid+200 mg/kg thymol; BT3, C+2,000 $\mathrm{mg} / \mathrm{kg}$ benzoic acid $+100 \mathrm{mg} / \mathrm{kg}$ thymol.

${ }^{\mathrm{a}-\mathrm{b}}$ Within a row, means without a common superscript differ $(\mathrm{p}<0.05$ or $\mathrm{p}<0.10)$. 
Table 9. Effect of benzoic acid and thymol on caecal microbial metabolism products of piglets

\begin{tabular}{|c|c|c|c|c|c|c|}
\hline \multirow{2}{*}{ Item } & \multicolumn{4}{|c|}{ Treatment $^{1}$} & \multirow{2}{*}{ SEM } & \multirow{2}{*}{ p-values } \\
\hline & $\mathrm{C}$ & BT1 & BT2 & BT3 & & \\
\hline \multicolumn{7}{|l|}{$14 \mathrm{~d}$} \\
\hline Acetic acid (mg/g) & 2.63 & 2.60 & 2.66 & 2.90 & 0.16 & 0.56 \\
\hline Propionic acid (mg/g) & 1.22 & 1.29 & 1.18 & 1.50 & 0.09 & 0.11 \\
\hline Butyric acid (mg/g) & 0.61 & 0.63 & 0.61 & 0.74 & 0.14 & 0.90 \\
\hline Total volatile fatty acid $(\mathrm{mg} / \mathrm{g})$ & $4.45^{\mathrm{b}}$ & $4.53^{\mathrm{b}}$ & $4.45^{\mathrm{b}}$ & $5.15^{\mathrm{a}}$ & 0.20 & 0.07 \\
\hline $\mathrm{NH}_{3}-\mathrm{N}(\mathrm{mg} / \mathrm{L})$ & $433^{\mathrm{a}}$ & $255^{\mathrm{b}}$ & $292^{\mathrm{b}}$ & $258^{\mathrm{b}}$ & 30.1 & $<0.01$ \\
\hline \multicolumn{7}{|l|}{$42 \mathrm{~d}$} \\
\hline Acetic acid (mg/g) & 2.18 & 2.17 & 2.34 & 2.76 & 0.24 & 0.32 \\
\hline Propionic acid (mg/g) & 1.12 & 1.25 & 1.36 & 1.51 & 0.11 & 0.10 \\
\hline Butyric acid (mg/g) & $0.73^{\mathrm{b}}$ & $0.99^{\mathrm{ab}}$ & $0.75^{\mathrm{b}}$ & $1.25^{\mathrm{a}}$ & 0.13 & 0.04 \\
\hline Total volatile fatty acid $(\mathrm{mg} / \mathrm{g})$ & 4.03 & 4.41 & 4.45 & 5.52 & 0.40 & 0.10 \\
\hline $\mathrm{NH}_{3}-\mathrm{N}(\mathrm{mg} / \mathrm{L})$ & $405^{\mathrm{a}}$ & $242^{\mathrm{b}}$ & $257^{\mathrm{b}}$ & $210^{\mathrm{b}}$ & 45.0 & 0.04 \\
\hline
\end{tabular}

SEM, standard error of the mean ( $\mathrm{n}=6$, number of replicates).

C, control, basal diet; BT1, C+1,000 mg/kg benzoic acid+100 mg/kg thymol; BT2, C+1,000 mg/kg benzoic acid+200 mg/kg thymol; BT3, C+2,000 $\mathrm{mg} / \mathrm{kg}$ benzoic acid $+100 \mathrm{mg} / \mathrm{kg}$ thymol.

${ }^{\mathrm{a}-\mathrm{b}}$ Within a row, means without a common superscript differ $(\mathrm{p}<0.05$ or $\mathrm{p}<0.10)$.

diets for the villous height in jejunum and ileum $(\mathrm{p}<0.10)$. and there were no differences among BTI, BT2, and BT3 On $\mathrm{d} 42$, pigs fed the BT1 diet tended to have an increased diets for the villous height in the ileum $(\mathrm{p}<0.10)$.

villous height in the ileum compared to diet treatment $\mathrm{C}$,

Table 10. Effect of benzoic acid and thymol on morphology of the small intestine of piglets

\begin{tabular}{|c|c|c|c|c|c|c|}
\hline \multirow{2}{*}{ Item } & \multicolumn{4}{|c|}{ Treatment $^{1}$} & \multirow{2}{*}{ SEM } & \multirow{2}{*}{ p-values } \\
\hline & $\mathrm{C}$ & BT1 & BT2 & BT3 & & \\
\hline \multicolumn{7}{|l|}{$14 \mathrm{~d}$ duodenum } \\
\hline Villus height $(\mu \mathrm{m})$ & 416 & 461 & 454 & 470 & 16.8 & 0.16 \\
\hline Crypt depth $(\mu \mathrm{m})$ & 182 & 181 & 163 & 174 & 11.1 & 0.60 \\
\hline Villus height:crypt depth & 2.32 & 2.64 & 2.80 & 2.73 & 0.17 & 0.22 \\
\hline \multicolumn{7}{|l|}{$14 \mathrm{~d}$ jejunum } \\
\hline Villus height $(\mu \mathrm{m})$ & $338^{\mathrm{b}}$ & $349^{\mathrm{b}}$ & $345^{\mathrm{b}}$ & $404^{\mathrm{a}}$ & 18.3 & 0.08 \\
\hline Crypt depth $(\mu \mathrm{m})$ & 165 & 143 & 141 & 159 & 9.61 & 0.27 \\
\hline Villus height:crypt depth & $2.10^{\mathrm{b}}$ & $2.46^{\mathrm{ab}}$ & $2.47^{\mathrm{ab}}$ & $2.59^{\mathrm{a}}$ & 0.12 & 0.04 \\
\hline \multicolumn{7}{|l|}{$14 \mathrm{~d}$ ileum } \\
\hline Villus height $(\mu \mathrm{m})$ & $288^{\mathrm{b}}$ & $339^{\mathrm{ab}}$ & $290^{\mathrm{b}}$ & $373^{\mathrm{a}}$ & 25.3 & 0.09 \\
\hline Crypt depth $(\mu \mathrm{m})$ & 136 & 134 & 121 & 137 & 8.32 & 0.51 \\
\hline Villus height:crypt depth & $2.12^{\mathrm{c}}$ & $2.51^{\mathrm{b}}$ & $2.40^{\mathrm{b}}$ & $2.77^{\mathrm{a}}$ & 0.11 & $<0.01$ \\
\hline \multicolumn{7}{|l|}{$42 \mathrm{~d}$ duodenum } \\
\hline Villus height $(\mu \mathrm{m})$ & 479 & 489 & 502 & 502 & 17.9 & 0.77 \\
\hline Crypt depth $(\mu \mathrm{m})$ & 208 & 199 & 204 & 201 & 7.16 & 0.83 \\
\hline Villus height:crypt depth & 2.31 & 2.47 & 2.47 & 2.50 & 0.08 & 0.38 \\
\hline \multicolumn{7}{|l|}{$42 \mathrm{~d}$ jejunum } \\
\hline Villus height $(\mu \mathrm{m})$ & 391 & 417 & 398 & 416 & 18.6 & 0.70 \\
\hline Crypt depth $(\mu \mathrm{m})$ & 167 & 164 & 167 & 165 & 10.5 & 0.99 \\
\hline Villus height:crypt depth & 2.36 & 2.36 & 2.40 & 2.55 & 0.11 & 0.49 \\
\hline \multicolumn{7}{|l|}{$42 \mathrm{~d}$ ileum } \\
\hline Villus height $(\mu \mathrm{m})$ & $345^{\mathrm{b}}$ & $405^{\mathrm{a}}$ & $380^{\mathrm{ab}}$ & $397^{\mathrm{ab}}$ & 15.6 & 0.07 \\
\hline Crypt depth $(\mu \mathrm{m})$ & 147 & 158 & 153 & 148 & 5.37 & 0.48 \\
\hline Villus height:crypt depth & 2.37 & 2.56 & 2.50 & 2.69 & 0.11 & 0.24 \\
\hline
\end{tabular}

SEM, standard error of the mean ( $\mathrm{n}=6$, number of replicates).

${ }^{1} \mathrm{C}$, control, basal diet; BT1, C+1,000 mg/kg benzoic acid+100 mg/kg thymol; BT2, C+1,000 mg/kg benzoic acid+200 mg/kg thymol; BT3, C+2,000 $\mathrm{mg} / \mathrm{kg}$ benzoic acid $+100 \mathrm{mg} / \mathrm{kg}$ thymol.

${ }^{\mathrm{a}-\mathrm{b}}$ Within a row, means without a common superscript differ $(\mathrm{p}<0.05$ or $\mathrm{p}<0.10)$ 


\section{DISCUSSION}

Recent studies have shown that benzoic acid $(\geq 5,000$ $\mathrm{mg} / \mathrm{kg}$ ) or thymol have positive effects on growth performance and health via their antibacterial action, but the effects of the combination of relatively low dose of benzoic acid $(<5,000 \mathrm{mg} / \mathrm{kg})$ and thymol on performance and health of weaned pigs is unknown. (Kluge et al., 2006; Janczyk et al., 2009).

Young pigs often face a decrease in production at the time of weaning, which results from post-weaning diarrhoea syndrome. It may be caused by lower digestive ability and/or a large number of pathogenic microbes living in the gut (Vondruskova et al., 2010). In Europe, as alternatives to antibiotics, benzoic acid and thymol have been used as effective supplements to improve growth performance and decrease diarrhoea in piglets. Previous studies have shown that $5,000 \mathrm{mg} / \mathrm{kg}$ benzoic acid supplementation in diets improved the growth performance in weaned or nursery pigs (Halas et al., 2010a; Papatsiros et al., 2011; Diao et al., 2013), and dietary $10,000 \mathrm{mg} / \mathrm{kg}$ thymol supplementation could decrease F/G in weaned pigs (Trevisi et al., 2010). In this study, F/G was decreased in pigs fed $2,000 \mathrm{mg} / \mathrm{kg}$ benzoic acid $+100 \mathrm{mg} / \mathrm{kg}$ thymol diet from $\mathrm{d} 0$ to 14 , which may have been due to the better gut characteristics including preferable digestibility, superior microenvironment and better morphology .

Some studies have shown that dietary $5,000 \mathrm{mg} / \mathrm{kg}$ benzoic acid supplementation decreased the incidence of diarrhoea in weaned pigs, and essential oil (containing thymol)-supplemented diet $(150 \mathrm{mg} / \mathrm{kg})$ reduced diarrhoea scores (Papatsiros et al., 2011; Li et al., 2012). In this study, dietary $2,000 \mathrm{mg} / \mathrm{kg}$ benzoic acid $+100 \mathrm{mg} / \mathrm{kg}$ thymol supplementation tended to decrease diarrhoea scores during the overall period. This could be due to the fact that benzoic acid and thymol inhibits the pathogenic Eschericha coli strains and helps to establish a proper balance between beneficial and pathogenic microbes in the intestine (Kluge et al., 2006; Li et al., 2012).

Proper acidity in the gut of piglets is one of the most important elements for the digestive system, as $\mathrm{pH}$ can affect the intestinal digestive enzymes activities and microflora of digesta (Efird et al., 1982). Halas et al. (2009) and Halas et al. (2010b) investigated the $\mathrm{pH}$ values of digesta in the digestive tract of weaned pigs and found that the results were similar and $\mathrm{pH}$ values were unaffected by the treatment of benzoic acid. However, Kluge et al. (2006) found that when compared with $5,000 \mathrm{mg} / \mathrm{kg}$ benzoic acid group, piglets supplemented with $10,000 \mathrm{mg} / \mathrm{kg}$ benzoic acid had significantly decreased $\mathrm{pH}$ values. There is currently no available information on the effect of thymol on $\mathrm{pH}$ values in the digesta of pigs, and thus there are no comparisons that could be made with other studies. Nevertheless, there have been some studies concerning plant essential oils which contained thymol. In an experiment with essential oil, no differences were observed among dietary treatments ( Manzanilla et al., 2009). In our study, no differences were observed among dietary treatments in $\mathrm{pH}$ values of the digesta, but there was a tendency towards lower $\mathrm{pH}$ values of the digesta in colon when pigs were fed a diet supplemented with $2,000 \mathrm{mg} / \mathrm{kg}$ benzoic acid+100 mg/kg thymol. This may be because of the fact that benzoic acid is a weak acid with high constant of dissociation and may have been present in the stomach and small intestine largely in a non-dissociated form, particularly when the additive dosage was low (Jensen, 2001). In addition, the lower $\mathrm{NH}_{3}-\mathrm{N}$ and greater SCFA concentrations observed in our study were likely to have indirect effect on $\mathrm{pH}$ values.

In our study, we also found that the ATTD of EE, Ca and crude ash were increased in pigs fed $2,000 \mathrm{mg} / \mathrm{kg}$ benzoic acid $+100 \mathrm{mg} / \mathrm{kg}$ thymol diet. Previous studies have shown that $5,000 \mathrm{mg} / \mathrm{kg}$ benzoic acid increased the digestibility of CP and EE (Guggenbuhl et al., 2007; Halas et al., 2009; Kluge et al., 2010), and $200 \mathrm{mg} / \mathrm{kg}$ plant essential oils (containing thymol) increased the ATTD of organic matter and starch (Manzanilla et al., 2009), which could be due to the higher digestive enzymes activities and better intestinal morphology. In addition, dietary benzoic acid and thymol supplementation increased the content of serum $\mathrm{Ca}$, which was generally related to the improved ATTD of Ca in this study.

The digestive enzymes synthesized and secreted by the pancreas contribute to nutrients digestion only after they reach the digestive tract and are activated, therefore, measuring the digestive enzymes activities in intestinal digesta, especially in jejunum could be valuable. In our study, pigs fed a diet supplemented with $2,000 \mathrm{mg} / \mathrm{kg}$ benzoic acid $+100 \mathrm{mg} / \mathrm{kg}$ thymol had increased activity of trypsin, lipase, amylase, maltase, lactase, and sucrase in jejunum digesta. Previous studies have reported that benzoic acid or organic acid increased the digestive enzymes activities in jejunum digesta (Risley et al., 1991; Diao et al., 2013). In addition, Jang et al. (2004) concluded that when compared with positive control (antibiotics), 25 $\mathrm{mg} / \mathrm{kg}$ plant essential oils $+1,000 \mathrm{mg} / \mathrm{kg}$ lactic acid increased the activity of trypsin and amylase in digesta of broilers while $25 \mathrm{mg} / \mathrm{kg}$ plant essential oils or $1,000 \mathrm{mg} / \mathrm{kg}$ lactic acid had no effects on digestive enzymes activities, which means that synergistic effects may exist between plant essential oil and organic acid on digestive enzymes activities.

However, a previous study has found that the intestine microbes are associated with nutrient digestion and 
absorption (Savage, 1986). Gut microbes are an integral part of gut health, and the increase of beneficial bacteria (Lactobacillus spp, Bifidobacterium spp, and Bacillus spp) and the decrease of harmful bacteria (pathogenic Eschericha coli) in the gut are associated with the intestinal morphology and diarrhea (Mikkelsen et al., 2003; Konstantinov et al., 2004; Vu Khac et al., 2006; Han et al., 2012). In our study, the population of Lactobacillus spp in pigs fed a diet supplemented with $2,000 \mathrm{mg} / \mathrm{kg}$ benzoic acid $+100 \mathrm{mg} / \mathrm{kg}$ thymol was greater than in pigs fed the $\mathrm{C}$ diet, while an increase of Bacillus spp and a decrease of Eschericha coli were found in all the additive diets. Previous studies have shown that diets supplemented with benzoic acid reduced the counts of pathogenic bacteria such as Eschericha coli and increased the counts of Lactobacillus spp in the gastrointestinal tract with a the lower $\mathrm{pH}$ in the gastric digesta (Richards et al., 2005; Kluge et al., 2006; Guggenbuhl et al., 2007). A similar result was observed in an experiment with thymol (Janczyk et al., 2009), which could be due thymol inhibiting bacteria according to its hydrophobicity, liposolubility and surface activity, causing protein denaturation of the pathogenic microbial cell wall and decomposeing the lipids of cell membrane and mitochondria. This changes the permeability of $\mathrm{K}^{+}$and $\mathrm{H}^{+}$making the cell wall permeable and leads the leakage of cell contents, additionally, phenol can effectively impede the oxidation of mitochondrial respiratory process and thus cause a the loss of energy in pathogenic microbes (Juven et al., 1994). Besides, since a combination of plant essential oils with organic acid showed synergistic activity, the plant essential oils could damage cell wall of pathogens, so that organic acid enters the inner of bacteria and inhibit them more easily (Vondruskova et al., 2010). In addition, lipopolysaccharides in the outer membrane of bacteria are strongly anionic and are stabilized by $\mathrm{Ca}^{2+}$ and $\mathrm{Mg}^{2+}$, and benzoic acid acts as chelating agent which can disrupt the outer membrane, resulting in increased sensitivity to other antimicrobial agents such as thymol (Zhou et al., 2007). Moreover, addition of an organic acid such as benzoic acid increases the concentration of $\mathrm{H}^{+}$, moves thymol in the molecular state and makes thymol freely permeable across the plasma membrane and allows thymol to exist in a form that can enter the bacterial cell and exert its antimicrobial activity (Zhou et al., 2007). Finally, Juven et al. (1994) concluded that when compared with $\mathrm{pH}$ values of 6.5 , thymol had better effects at $\mathrm{pH}$ of 5.5 in inhibiting salmonella and staphylococcus aureus, due to less decomposition in lower $\mathrm{pH}$ values, leading higher hydrophobicity, and thus combining more protein hydrophobic areas. However, the $\mathrm{pH}$ values in our study were not altered except for a tendency towards lower values was found in the colon, so the specific mechanism need further research.

The change of gut microbial composition leads to the variation in microbial metabolites. The SCFAs are not only positive in providing energy for intestinal epithelial cells but also promote the formation of cells through stabilizing DNA and repairing damage, and thus improve intestinal morphology (Burns and Rozengurt, 1984). Furthermore, SCFAs can inhibit bacteria through increasing the acidity of intercellular substance in harmful bacteria, destroying the balance of osmotic pressure in harmful bacteria, and thus play a role in regulating mircoflora (Corrier et al., 1990). $\mathrm{NH}_{3}-\mathrm{N}$ is a kind of alkaline nitrogenous substance which comes from undigested protein and is decomposed by bacteria and produce ammonia and amine in the gut, and the increase of ammonia nitrogen has an adverse effect on the development of intestinal mucosa (Dong et al., 1997). In our study, a greater concentration of butyric acid in pigs fed a diet supplemented with $2,000 \mathrm{mg} / \mathrm{kg}$ benzoic acid +100 $\mathrm{mg} / \mathrm{kg}$ thymol was observed and a lower concentration of $\mathrm{NH}_{3}-\mathrm{N}$ was observed in caecal digesta, which is generally consistent with previous studies regarding benzoic acid or thymol in piglets (Cho et al., 2006; Manzanilla et al., 2006; Buhler et al., 2009). Gianluca et al. (2011) found a decrease of $\mathrm{NH}_{3}-\mathrm{N}$ emission from pig slurry with the addition of benzoic acid to their diet, and Cho et al. (2006) reported that piglets fed a diet supplemented with $300 \mathrm{mg} / \mathrm{kg}$ plant essential oils had a decreased concentration of $\mathrm{NH}_{3}-\mathrm{N}$ in their feces, which suggested dietary supplementation with benzoic acid and thymol could produce relatively lower microbial toxicity metabolites. Bühler et al. (2009) reported that the concentration of butyric acid increased in the caecum and colon with the addition of benzoic acid in the diet. Studies by Manzanilla et al. (2006) and Manzanilla et al. (2009) showed that the concentration of butyric acid in digesta of the cecum and colon increased when $200 \mathrm{mg} / \mathrm{kg}$ or $300 \mathrm{mg} / \mathrm{kg}$ plant essential oils was added. The positive influence of benzoic acid and thymol on butyric acid may be connected with the fermentation of amylose in wheat and barley, and the modification in bacterial populations contribute to the variation of SCFAs (Halas et al., 2010b). Thus, benzoic acid and thymol could improve gut health through regulating microbial metabolites.

The reduction of villus height may decrease the absorptive area of total luminal villus, which could result in inadequate digestive enzyme development and lower digestibility (Cera et al., 1988). Therefore, measurement of intestinal morphology was used to evaluate the digestive function of the intestine. In our study, we found that the villous height to crypt depth ratio in jejunum and ileum in pigs fed diet supplemented with $2,000 \mathrm{mg} / \mathrm{kg}$ benzoic acid+100 mg/kg thymol was greater. Recent studies have shown that pigs fed a diet supplemented with benzoic acid 
had higher villus height in the ileum, and dietary supplementation with thymol was found to increase the villus height to crypt depth ratio in jejunum (Manzanilla et al., 2009; Michiels, 2009; Halas et al., 2010a), which is consistent with the results of our study. Lupton and Jacobs. (1987) showed that $\mathrm{pH}$ value affected cell growth, and cell division was improved with the increase of acidity. Other research found that the reduction of intestinal villus height and increase of crypt depth of piglets was related to the decrease of sucrase and lactase activities in the striated border (Hampson and Kidder, 1986), which suggested the combination of benzoic acid and thymol in this study can alleviate intestinal stress of piglets by lowering intestinal $\mathrm{pH}$ value, increasing the small intestine digestive enzyme activities and improving intestinal morphology after weaning.

\section{CONCLUSION}

In conclusion, piglets fed diets supplemented with different concentrations/combinations of benzoic acid and thymol had improved growth performance. It appears that benzoic acid and thymol may promote nutrient digestion and absorption, reduce diarrhea and maintain a favourable gut micro-environment. The combination of $2,000 \mathrm{mg} / \mathrm{kg}$ benzoic acid $+100 \mathrm{mg} / \mathrm{kg}$ thymol showed better effects than the other treatments in most measurements.

\section{ACKNOWLEDGMENTS}

This study was supported by DSM (China) Limited and the China Pig Modern Industrial Technology System (CARS-36). The authors do not have a conflict of interest.

\section{REFERENCES}

AOAC. 1995. Official Methods of Analysis. 16th edn. Association of Official Analytical Chemists. Washington, DC, USA.

Aarnink, A. J. A. and M. W. A. Verstegen. 2007. Nutrition, key factor to reduce environmental load from pig production. Livest. Sci. 109:194-203.

Bühler, K., B. Bucher, C. Wenk, and J. Broz. 2009. Influence of benzoic acid in high fibre diets on nutrient digestibility and VFA production in growing/finishing pigs. Arch. Anim. Nutr. 63:127-136.

Burns, C. P. and E. Rozengurt. 1984. Extracellular $\mathrm{Na}^{+}$and initiation of DNA synthesis: Role of intracellular $\mathrm{pH}$ and $\mathrm{K}^{+}$. J. Cell Biol. 98:1082-1089.

Cera, K. R., D. C. Mahan, R. F. Cross, G. A. Reinhart, and R. E. Whitmoyer. 1988. Effect of age, weaning and postweaning diet on small intestinal growth and jejunal morphology in young swine. J. Anim. Sci. 66:574-584.

Chen, H., X. Mao, J. He, B. Yu, Z. Huang, J. Yu, P. Zheng, and D. Chen. 2013. Dietary fibre affects intestinal mucosal barrier function and regulates intestinal bacteria in weaning piglets. Br. J. Nutr. 110:1837-1848.

Cho, J. H., Y. J. Chen, B. J. Min, H. J. Kim, O. S. Kwon, K. S. Shon, I. H. Kim, S. J. Kim, and A. Asamer. 2006. Effects of essential oils supplementation on growth performance, IgG concentration and fecal noxious gas concentration of weaned pigs. Asian Australas. J. Anim. Sci. 19:80-85.

Corrier, D. E., A. Hinton Jr, R. L. Ziprin, and J. R. DeLoach. 1990. Effect of dietary lactose on Salmonella colonization of marketage broiler chickens. Avian Dis. 34:668-676.

Diao, H., P. Zheng, B. Yu, J. He, X. B. Mao, J. Yu, Z. Q. Huang, L. Dai, Q. Y. Wang, and D. W. Chen. 2013. Effects of benzoic acid on growth performance, serum biochemical parameters, nutrient digestibility and digestive enzymes activities of jejuna digesta in weaner piglets. Chn. J. Anim. Nutr. 25:768-777.

Dong, G. Z., A. G. Zhou, F. Yang, and K. Cken. 1997. Effect of dietary protein level on nitrogen metabolism in early-weaned pigs. Chn. J. Anim. Nutr. 2:19-24.

Efird, R. C., W. D. Armstrong, and D. L. Herman. 1982. The development of digestive capacity in young pigs: effects of age and weaning system. J. Anim. Sci. 55:1380-1387.

Fierer, N., J. A. Jackson, R. Vilgalys, and R. B. Jackson. 2005. Assessment of soil microbial community structure by use of taxon-specific quantitative PCR assays. Appl. Environ. Microbiol. 71:4117-4120.

GB/T 23742. 2009. Measurement of the Acid Insoluble Ash in Feed. Standards press of China, Beijing, China.

Gianluca, G., L. Malagutti, S. Colombini, L. Rapetti, and G. Matteo Crovetto. 2011. Effects of benzoic acid on nitrogen, phosphorus and energy balance and on ammonia emission from slurries in the heavy pig. Ital. J. Anim. Sci. 10:e38.

Giannenas, I., C. P. Papaneophytou, E. Tsalie, I. Pappas, E. Triantafillou, D. Tontis, and G. A. Kontopidis. 2014. Dietary supplementation of benzoic acid and essential oil compounds affects buffering capacity of the feeds, performance of turkey poults and their antioxidant status, $\mathrm{pH}$ in the digestive tract, intestinal microbiota and morphology. Asian Australas. J. Anim. Sci. 27:225-236.

Guggenbuhl, P., A. Séon, A. Piñón Quintana, and C. Simões Nunes. 2007. Effects of dietary supplementation with benzoic acid (VevoVitall ${ }^{\circledR}$ ) on the zootechnical performance, the gastrointestinal microflora and the ileal digestibility of the young pig. Livest. Sci. 108:218-221.

Halas, D., C. F. Hansen, D. J. Hampson, B. P. Mullan, J. C. Kim, R. H. Wilson, and J. R. Pluske. 2010a. Dietary supplementation with benzoic acid improves apparent ileal digestibility of total nitrogen and increases villous height and caecal microbial diversity in weaner pigs. Anim. Feed. Sci. 160:137-147.

Halas, D., C. F. Hansen, D. J. Hampson, J.-C. Kim, B. P. Mullan, R. H. Wilson, and J. R. Pluske. 2010b. Effects of benzoic acid and inulin on ammonia-nitrogen excretion, plasma urea levels, and the $\mathrm{pH}$ in faeces and urine of weaner pigs. Livest. Sci. 134:243-245.

Halas, D., C. F. Hansen, D. J. Hampson, B. P. Mullan, R. H. Wilson, and J. R. Pluske. 2009. Effect of dietary supplementation with inulin and/or benzoic acid on the incidence and severity of post-weaning diarrhoea in weaner pigs after experimental challenge with enterotoxigenic 
Escherichia coli. Arch. Anim. Nutr. 63:267-280.

Hampson, D. J. and D. E. Kidder. 1986. Influence of creep feeding and weaning on brush border enzyme activities in the piglet small intestine. Res. Vet. Sci. 40:24-31.

Han, G. Q., Z. T. Xiang, B. Yu, D. W. Chen, H. W. Qi, X. B. Mao, H. Chen, Q. Mao, and Z. Q. Huang. 2012. Effects of different starch sources on Bacillus spp. in intestinal tract and expression of intestinal development related genes of weanling piglets. Mol. Biol. Rep. 39:1869-1876.

Hildebrandt, M. A., C. Hoffmann, S. A. Sherrill-Mix, S. A. Keilbaugh, M. Hamady, Y. Y. Chen, R. Knight, R. S. Ahima, F. Bushman, and G. D. Wu. 2009. High-fat diet determines the composition of the murine gut microbiome independently of obesity. Gastroenterology 137:1716-1724 e1711-1712.

Janczyk, P., R. Pieper, V. Urubschurov, K. R. Wendler, and W. B. Souffrant. 2009. Investigations on the effects of dietary essential oils and different husbandry conditions on the gut ecology in piglets after weaning. Int. J. Microbiol. 2009 Article ID 730809.

Jang, I. S., Y. H. Ko, H. Y. Yang, J. S. Ha, J. Y. Kim, S. Y. Kang, D. H. Yoo, D. S. Nam, D. H. Kim, and C. Y. Lee. 2004. Influence of essential oil components on growth performance and the functional activity of the pancreas and small intestine in broiler chickens. Asian Australas. J. Anim. Sci. 17:394-400.

Jensen, B. B. 2001. Possible ways of modifying type and amount of products from microbial fermentation in the gut. In: 8th Symposium on Digestive Physiology in Pigs. Uppsala, Sweden. pp. 181-200.

Juven, B. J., J. Kanner, F. Schved, and H. Weisslowicz. 1994. Factors that interact with the antibacterial action of thyme essential oil and its active constituents. J. Appl. Microbiol. 76:626-631.

Klein, G., C. Ruben, and M. Upmann. 2013. Antimicrobial activity of essential oil components against potential food spoilage microorganisms. Curr. Microbiol. 67:200-208.

Kluge, H., J. Broz, and K. Eder. 2006. Effect of benzoic acid on growth performance, nutrient digestibility, nitrogen balance, gastrointestinal microflora and parameters of microbial metabolism in piglets. J. Anim. Physiol. Anim. Nutr. 90:316324.

Kluge, H., J. Broz, and K. Eder. 2010. Effects of dietary benzoic acid on urinary $\mathrm{pH}$ and nutrient digestibility in lactating sows. Livest. Sci. 134:119-121.

Konstantinov, S. R., A. Awati, H. Smidt, B. A. Williams, A. D. L. Akkermans, and W. M. de Vos. 2004. Specific response of a novel and abundant Lactobacillus amylovorus-like phylotype to dietary prebiotics in the guts of weaning piglets. Appl. Environ. Microbiol. 70:3821-3830.

Lee, K.-W., H. Everts, H. J. Kappert, M. Frehner, R. Losa, and A. C. Beynen. 2003. Effects of dietary essential oil components on growth performance, digestive enzymes and lipid metabolism in female broiler chickens. Br. Poult. Sci. 44:450457.

Li, S., Y. J. Ru, M. Liu, B. Xu, A. Péron, and X. G. Shi. 2012. The effect of essential oils on performance, immunity and gut microbial population in weaner pigs. Livest. Sci. 145:119-123.

Luna, A., M. C. Labaque, J. A. Zygadlo, and R. H. Marin. 2010. Effects of thymol and carvacrol feed supplementation on lipid oxidation in broiler meat. Poult. sci. 89:366-370.
Lupton, J. R. and L. R. Jacobs. 1987. Fiber supplementation results in expanded proliferative zones in rat gastric mucosa. Am. J. Clin. Nutr. 46:980-984.

Manzanilla, E. G., M. Nofrarias, M. Anguita, M. Castillo, J. F. Perez, S. M. Martín-Orúe, C. Kamel, and J. Gasa. 2006. Effects of butyrate, avilamycin, and a plant extract combination on the intestinal equilibrium of early-weaned pigs. J. Anim. Sci. 84:2743-2751.

Manzanilla, E. G., J. F. Pérez, M. Martín, J. C. Blandón, F. Baucells, C. Kamel, and J. Gasa. 2009. Dietary protein modifies effect of plant extracts in the intestinal ecosystem of the pig at weaning. J. Anim. Sci. 87:2029-2037.

Michiels J. 2009. Effect of Essential Oils on Gut Bacteria and Functionality in the Pig. Ph.D. Thesis, Ghent University, Ghent, Belgium.

Mikkelsen, L. L., C. Bendixen, M. Jakobsen, and B. B. Jensen. 2003. Enumeration of bifidobacteria in gastrointestinal samples from piglets. Appl. Environ. Microbiol. 69:654-658.

Mroz, Z. 2005. Organic acids as potential alternatives to antibiotic growth promoters for pigs. Adv. Pork Prod. 16:169-181.

National Research Council. 1998. Nutrient Requirements of Swine. 10th ED. National Academy Press, Washington, DC, USA.

Papatsiros, V. G., P. D. Tassis, E. D. Tzika, D. S. Papaioannou, E. Petridou, C. Alexopoulos, and S. C. Kyriakis. 2011. Effect of benzoic acid and combination of benzoic acid with a probiotic containing Bacillus cereus var. toyoi in weaned pig nutrition. Pol. J. Vet. Sci. 14:117-125.

Pluske, J. R., I. H. Williams, and F. X. Aherne. 1996. Maintenance of villous height and crypt depth in piglets by providing continuous nutrition after weaning. Anim. Sci. 62:131-144.

Qi, H. W., Z. T. Xiang, G. Q. Han, B. Yu, Z. Q. Huang, and D. W. Chen. 2011. Effects of different dietary protein sources on cecal microflora in rats. Afr. J. Biotechnol. 10:3704-3708.

Richards, J. D., J. Gong, and C. F. M. De Lange. 2005. The gastrointestinal microbiota and its role in monogastric nutrition and health with an emphasis on pigs: Current understanding, possible modulations, and new technologies for ecological studies. Can. J. Anim. Sci. 85:421-435.

Risley, C. R., E T. Kornegay, M. D. Lindemann, and S. M. Weakland. 1991. Effects of organic acids with and without a microbial culture on performance and gastrointestinal tract measurements of weanling pigs. Anim. Feed. Sci. Technol. 35:259-270.

Savage, D. C. 1986. Gastrointestinal microflora in mammalian nutrition. Annu. Rev. Nutr. 6:155-178.

Torrallardona, D., I. Badiola, and J. Broz. 2007. Effects of benzoic acid on performance and ecology of gastrointestinal microbiota in weaned piglets. Livest. Sci. 108:210-213.

Trevisi, P., G. Merialdi, M. Mazzoni, L. Casini, C. Tittarelli, S. De Filippi, L. Minieri, G. Lalatta-Costerbosa, and P. Bosi. 2010. Effect of dietary addition of thymol on growth, salivary and gastric function, immune response, and excretion of Salmonella enterica serovar Typhimurium, in weaning pigs challenged with this microbe strain. Ital. J. Anim. Sci. 6:374376.

Vondruskova, H., R. Slamova, M. Trckova, Z. Zraly, and I. Pavlik. 2010. Alternatives to antibiotic growth promoters in prevention of diarrhoea in weaned piglets: A review. Vet. Med-cz. 55:199224. 

Vu Khac, H., E. Holoda, E. Pilipcinec, M. Blanco, J. E. Blanco, A.
Mora, G. Dahbi, C. Lopez, E. A. Gonzalez, and J. Blanco. 2006. Serotypes, virulence genes, and PFGE profiles of Escherichia coli isolated from pigs with postweaning diarrhoea in Slovakia. BMC Vet. Res. 2:10.
Zhou, F., B. Ji, H. Zhang, H. Jiang, Z. Yang, J. Li, Y. Ren, and W. Yan. 2007. Synergistic effect of thymol and carvacrol combined with chelators and organic acids against Salmonella Typhimurium. J. Food Protect. 70:1704-1709. 